\title{
立位・膝立ち位における前方リーチ動作の比較
}

一筋電困を用いて一

\section{Comparison of Reaching Forward between Standing and Kneeling}

\section{兵頭 甲子太郎1) 丸山 仁司 ${ }^{2)}$}

KASHITARO HYODO ${ }^{1)}$, Hitoshi MARUYAMA ${ }^{2)}$

1) Department of Physical Therapy, Faculty of Health Science, Mejiro College: 320 Ukiya, Iwatuki-ku, Saitama-city, Saitama 3398501, Japan. TEL +81 48-797-2131

2) Department of Physical Therapy, Faculty of Health Science, International University of Health and Wealfare

Rigakuryoho Kagaku 23(2): 183-187, 2008. Submitted Jun. 28, 2007. Accepted Oct. 19, 2007.

ABSTRACT: The aim of this investigation was to examine changes of electromyogram activity when subjects performed two kinds of reaching forward in standing and kneeling. Eleven healthy subjects with a mean age of $25.63 \pm$ 1.86 years participated in this study. They performed reaching forward of two kinds as a motor task. Electromyography (EMG) of gluteus maximus (GM), biceps femoris (BF), rectus abdominis (RA), and erector spinae (ES) was measured in the reaching position and the distance of reach was measured. EMG of BF in kneeling was higher than in standing. Changes of EMG were shown in the two kinds of reaching forward. These results suggest that specific motor activity is facilitated by changing position and movement method.

Key words: reaching forward, kneeling, electromyography

要旨: 本研究の目的は, 立位・膝立ち位にて2種類のリーチ動作を行わせ, 肢位や施行方法の違いによる筋電図学的変 化について検討していくことである。対象は整形外科的疾患の既住のない健常成人 11 名とし, 立位・膝立ち位それぞ

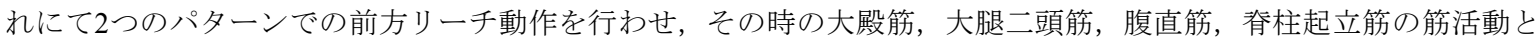
リーチ距離を測定した。実験の結果から，膝立ち位では立位と比べ大腿二頭筋の筋活動の割合の増加がみられた。ま

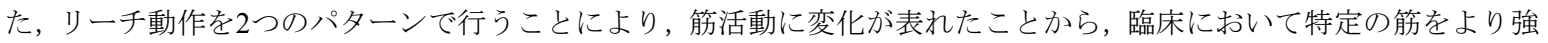
調した形での動作が可能になるのではないかと考えている。

キーワード : 前方リーチ動作, 膝立ち位, 筋電図

1) 目白大学 保健医療学部理学療法学科：埼玉県さいたま市岩槻区浮谷320（テ339-8501） TEL 048-797-2131

2) 国際医療福祉大学 保健医療学部理学療法学科

受付日 2007年6月28日＼cjkstart受理日２007年10月19日 


\section{I. はじめに}

膝立ち位は立位と比べ重心の位置が低く転倒の危険 性が低いといった利点や, 支持基底面・重心点が異な るため, 立位での評価・治療とは異なった効果が期待 できることが予測される。このような観点から，近年 では重心動摇計や筋電図を用いた膝立ち位に関する報 告1-4)もなされているが，まだその数は少なく，明らか になっていない部分が多い。

立位における重心動摇計や筋電図を用いた研究は多 くのものが報告されており, 様々な評価方法の開発も なされてきた。その中の 1 つに, Duncan らが開発した 前方リーチ動作を用いた Functional Reach Test（FRT）が ある5,6)。の前方リーチ動作は評価としてだけでなく, 立位動作や歩行時における前方への重心移動困難な患 者への治療手技の 1 つしても用いられることがある。 通常, この動作を行った場合, 股関節を屈曲させ, 上 体を屈曲させるとともに, 骨盤を後方へ引いて, 身体 重心の前方変位に抵抗するような姿勢制御がなされる。 しかし，下肢の支持力に低下がみられている患者では， 支持力の低下した下肢で体重を支持することを避ける ために, 過度に股関節を屈曲させる代償動作がみられ ることがある7)。また, 同様に高齢者においても過度な 股関節の屈曲による股関節ストラテジーを中心とした 姿勢制御が行われるとの報告もある8)。

そこで，今回は前方リーチ動作の施行方法を(1)通常 の股関節を屈曲し, 骨盤を後方へ引いてのリーチ動作 と(2)股関節の屈曲と骨盤を引く動作を行わせないもの, との $2 つ に$ 設定し, この 2 つの動作を立位・膝立ち位に て行わせ, 肢位や施行方法の違いによる筋電図学的変 化について検討していくこととした。

\section{II. 対象と方法}

\section{1. 対象}

対象は, 本研究の目的, 方法を説明し同意を得た整 形外科的疾患の既住のない健常成人 11名（男性：7名, 女性 : 4 名) で, 平均年齢 : $25.6 \pm 1.9$ 歳, 平均身長 : $168.0 \pm 9.6 \mathrm{~cm}$, 平均体重 : $61.5 \pm 11.1 \mathrm{~kg}$ であった。

\section{2. 方法}

(1)課題 (図 1)

運動課題は1）通常の股関節を屈曲し，骨盤を後方へ 引いての立位での前方リーチ動作 (以下: 立位リーチ), 2）同様の施行方法での, 膝立ち位での前方リーチ動作
(以下: 膝立ち位リーチ)，3）股関節の屈曲と骨盤を引 く動作を行わせない形での, 立位での前方リーチ動作 (以下：立位リーチ(2)，4）同様の施行方法での，膝立 ち位での前方リーチ動作 (以下: 膝立ち位リーチ(2))の 4つとした。

開始肢位は 4 動作ともに右上肢を $90^{\circ}$ 挙上し, 肩幅 程度の開脚位とした。その位置から最大限前方にリー 于動作を行い, 10 秒間の保持を行わせ, 大殿筋, 大腿 二頭筋，腹直筋，脊柱起立筋における活動電位を導出 した。この一連の動作を 5 秒間の休毠を挟みながら連 続3 回施行し, 同時にリーチ距離の測定を行った。

また, 今回は静止肢位との比較を行うため, 課題施 行前に右上肢を $90^{\circ}$ 挙上した静止立位・静止膝立ち位 の開始肢位での 10 秒間の保持を行わせた。

被験者には最大限上肢を伸ばした位置を保持するこ と, 課題3），4）にて骨盤を引く動作を行わないように との指示のみを与え, 数回の練習の後測定を行った。

(2)筋電図の測定

測定には Mega electronics 社製 ME3000 筋電計を用い, 被験筋は右の大殿筋, 大腿二頭筋, 腹直筋, 脊柱起立 筋の 4 筋とし, 双極性表面電極 2 個を電極中心間隔 $3 \mathrm{~cm}$ で貼付した。得られたデータはサンプリング周波数 1000 $\mathrm{Hz}$ にて $\mathrm{A} / \mathrm{D}$ 変換し，パーソナルコンピューター $(\mathrm{PC})$ に保存した。10 秒間の課題施行時の波形から最大值を 採用し, 各筋の 10 秒間の最大等尺性収縮時の最大值を $100 \%$ として正規化し，\%MVCとして表した。また，今 回は3 回の連続動作での\%MVC の平均值を採用し, 各 筋の最大等尺性収縮はDanielらの徒手筋力法に従い行っ た。

(3)統計学的処理

1）大殿筋，大腿二頭筋，腹直筋，春柱起立筋の 4 筋 での静止立位, 静止膝立ち位, 各課題動作 $6 つ の$ 間にお ける\%MVCの比較，2）静止立位, 静止膝立ち位, 各課 題動作での各筋間における\%MVC の比較，3）各課題 動作でのリーチ距離の比較を1元配置の分散分析, TukeyKramer の多重比較検定を用いて行った。なお, 有意水 準は $5 \%$ 未満とした。

\section{III. 結 果}

各動作における各筋の\%MVC と統計学的処理 1）2) の結果を表 1 に, 各動作におけるリーチ距離と統計学 的処理3）の結果を表2 に示す。

統計学的処理 1)の4筋での静止立位・静止膝立ち位, 各課題動作6つの間における\%MVCの比較では, 表 1 に 


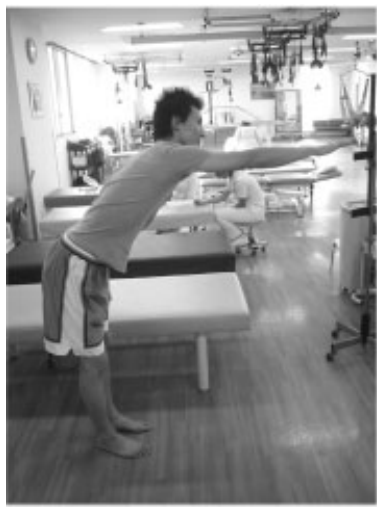

立位での前方リーチ動作

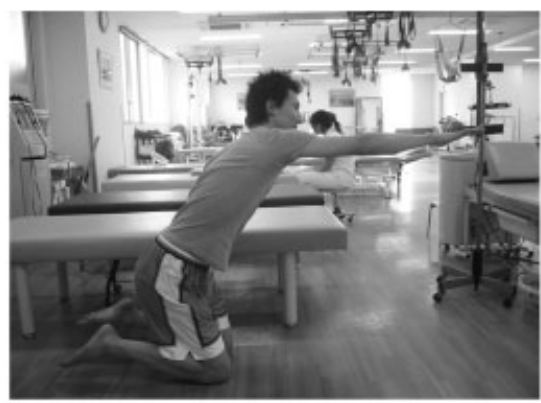

膝立ち位での前方リーチ動作

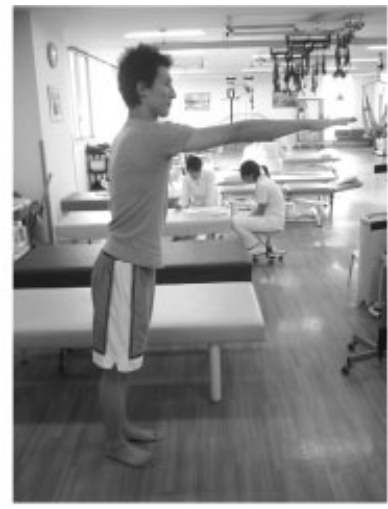

立位での前方リーチ動作(2)

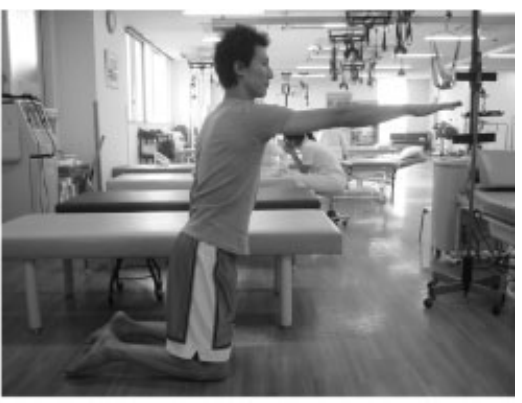

膝立ち位での前方リーチ動作(2)

図14つの運動課題

表1 各動作における各筋の\%MVC平均值と標準偏差

\begin{tabular}{|c|c|c|c|c|c|}
\hline & 大殿筋 & 大腿二頭筋 & 腹直筋 & 脊柱起立筋 & \\
\hline 静止立位 & $2.9 \pm 2.8$ & $2.0 \pm 1.8$ & $4.1 \pm 2.8$ & $10.0 \pm 3.4$ & *3)),5)),6)) \\
\hline 立位リーチ & $11.9 \pm 5.6$ & $28.1 \pm 1.4$ & $7.5 \pm 3.3$ & $45.1 \pm 1.8$ & $* *(1)), 5)) * 3()), 4)), 6))$ \\
\hline 立位リーチ(2) & $25.3 \pm 1.6$ & $23.7 \pm 1.9$ & $6.2 \pm 3.6$ & $29.8 \pm 1.4$ & $* * 2)), 4)) * 6)$ ) \\
\hline 静止膝立ち位 & $4.2 \pm 4.2$ & $6.9 \pm 6.9$ & $3.7 \pm 2.6$ & $13.1 \pm 7.4$ & *3)),6)) \\
\hline 膝立ち位リーチ & $17.6 \pm 8.3$ & $39 \pm 21.3$ & $6.0 \pm 3.9$ & $53.2 \pm 24.8$ & $* * 1)) * 3()), 4)), 6))$ \\
\hline 膝立ち位リーチ(2) & $\begin{array}{r}19.6 \pm 7.8 \\
* * 10) \\
* 1), 3)-5) \\
7)-9)\end{array}$ & $\begin{array}{c}42.5 \pm 27.5 \\
* 1), 2), 4) \\
5), 8), 9)\end{array}$ & $\begin{array}{r}5.5 \pm 2.7 \\
* 1), 2) \\
4)-9)\end{array}$ & $35.4 \pm 13.4$ & $* * 1)) * 4)), 6))$ \\
\hline
\end{tabular}

1）静止立位と静止膝立ち位，2）静止立位と立位リーチ，3）静止立位と立位リーチ(2)，4）静止立位と膝立ち位リー チ，5）静止立位と膝立ち位リーチ(2，6）膝立ち位と立位リーチ，7）膝立ち位と立位リーチ(2)，8）膝立ち位と膝 立ち位リーチ，9）膝立ち位と膝立ち位リーチ(2)，10）立位リーチと立位リーチ(2)

1)) 大殿筋と大腿二頭筋，2)) 大殿筋と腹直筋，3)) 大殿筋と脊柱起立筋，4)) 大腿二頭筋と腹直筋，5))大腿二頭筋と脊柱 起立筋, 6))腹直筋と脊柱起立筋の各 $\quad * \mathrm{p}<0.01, * * \mathrm{p}<0.05$

示す通り, 静止立位と各課題動作, 静止膝立ち位と各 課題動作間の比較では腹直筋を除き，ほぼす心゙てにお いて有意差が認められる結果となった。また, 各課題 動作間の比較では大殿筋での立位リーチと立位リーチ (2)間においてのみ有意差が認められた。
統計学的処理 2) の静止立位, 静止膝立ち位, 各課題 動作での各筋間における\%MVCの比較では, 静止立位. 立位リーチでは，春柱起立筋が他の 3 筋と比べ優位に 高い值を示すのに対し, 静止膝立ち位・膝立ち位リー チでは脊柱起立筋と大腿二頭筋との間に有意差が認め 
表2 リーチ距離平均值 $(\mathrm{cm})$

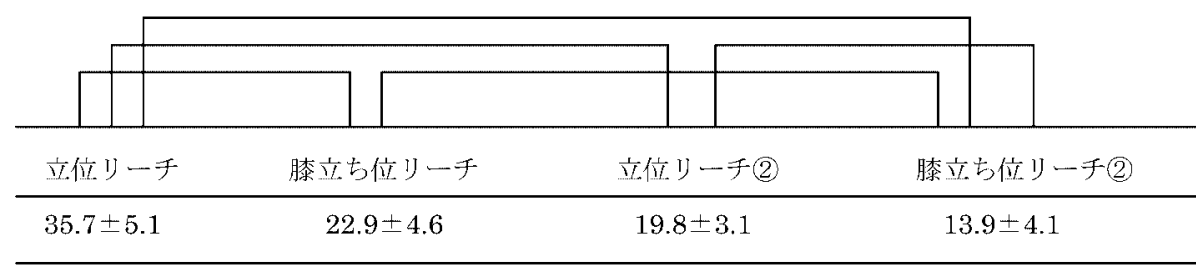

これら組み合わせにて $\mathrm{p}<0.01$ にて有意差あり.

られない結果となった。また，立位リーチ，膝立ち位 リーチでは大腿二頭筋も大殿筋・腹直筋と比べ優位に 高い值を示している。立位リーチ(2)では春柱起立筋は 腹直筋との間でのみ有意差が認められ, 他の動作と異 なり, 大殿筋が腹直筋と比べ優位に高い值を示し, 膝 立ち位リーチ(2)では立位リーチ, 膝立ち位リーチと同 様大腿二頭筋が大殿筋・腹直筋と比べ優位に高い值を 示す結果となった。

統計学的処理 3)の各動作間におけるリーチ距離の比 較では膝立ち位リーチと立位リーチ(2)との間を除き, その他の間においては $<0.01 に て$ 有意差が認められた。

\section{IV. 考 察}

今回の実験では, 静止立位, 静止膝立ち位での比較 では，大殿筋，大腿二頭筋，腹直筋，脊柱起立筋 4 筋と も有意差が認められなかった。盛らの行った立位と膝 立ち位の筋電図を用いた比較でも有意差は認められな かったとしており1)，今回の結果と一致していると思 われる。しかし, 静止立位, 静止膝立ち位それぞれで の4筋の比較では静止立位では脊柱起立筋が他の3筋に 比べ有意に高い值を示しているのに対し, 静止膝立ち 位では春柱起立筋と大腿二頭筋の間に有意差が認めら れず, 立位と比べ, 膝立ち位にて大腿二頭筋の 4 筋全体 での筋活動の割合が大きくなっていることを示してい ると思われる。膝立ち位は, 股関節伸展, 膝関節屈曲 位での姿勢保持となるため，これら 2 つの作用を持つ 二関節筋である大腿二頭筋の活動が増加したものと考 えられる。

また, 静止立位と各課題動作間, 静止膝立ち位と各 課題動作間とを比較した結果では，有意差は認められ たものの, 各課題動作間どうしの比較では大殿筋での 立位リーチ・立位リーチ(2)間での比較のみ有意差を認 め,その他では認められなかった。このことから, 立 位, 膝立ち位といった肢位の変化や, 動作施行方法の
変化では大きな筋活動の増加は起こらないものと思わ れる。

各課題動作での 4 筋の筋活動の比較を行った結果で は，立位リーチでは春柱起立筋が他の 3 筋と比べ有意 に高い值を示しており，大腿二頭筋は大殿筋・腹直筋 と比べ高い值を示す結果となった。これに対して膝立 ち位リーチでは春柱起立筋は大殿筋・腹直筋とのみ有 意差を示しており，大腿二頭筋は立位リーチ時と変わ らず大殿筋・腹直筋と有意差を示している。このこと は，前方リーチ動作では立位と比べ，膝立ち位での動 作にて大腿二頭筋の全体における筋活動の割合が増加 することを示している。また，立位リーチ動作(2)では 春柱起立筋は腹直筋とのみ有意差を示しており, 大腿 二頭筋・大殿筋も同様に腹直筋とのみ有意差を示して おり，立位リーチ動作と比べ，大殿筋の全体における 筋活動の割合が増加している。膝立ち位リーチ(2)では, 春柱起立筋は腹直筋と, 大腿二頭筋は腹直筋と大殿筋 と有意差を示しており，全体における大腿二頭筋の筋 活動の割合が 4 つの課題の中で最も増加を示す結果と なった。

これらの結果をまとめると，大殿筋は立位リーチ(2) にて, 大腿二頭筋は膝立ち位リーチ・膝立ち位リーチ (2)にて，春柱起立筋は全体を通して他の筋と比べ高い 筋活動が得られることがわかった。また，体幹前面筋 である腹直筋はどの動作においても他の筋に比べ筋活 動が低い結果となり, 動作間における変化も認められ なかった。

通常の前方リーチ動作では，前述したように，股関 節を屈曲させ，上体を屈曲させるとともに，骨盤を後 方へ引いて身体重心の前方変位に抵抗するような姿勢 制御がなされる。この時，立位での前方リーチ動作で は，大殿筋は股関節部に対して遠心性での活動が必要 となり，大腿二頭筋は二関節筋であるため，股関節・ 膝関節両部において遠心性の活動が必要となる。これ に対し，膝立ち位での動作では大腿二頭筋の膝関節部 
における働きが遠心性から求心性に変化すると考えら れる。膝立ち位では重心線が基底面である両下腿の前 縁にあるため, 前方への重心移動が起こった際に重心 を基底面内に収めることが難しい。このことは, 鏑木 らの行った実験でも, 膝立ち位は立位に比べ左右動摇 幅には有意差が認められなかったが, 前後動摇幅は有 意に大きかったと報告されている2)。今回の実験にお いても, 立位での前方リーチ距離に比べ, 膝立ち位で の前方リーチ距離は減少しており, 重心の前方移動の 困難さがあったものと考えられる。そのため, 膝立ち 位にて前方リーチ動作を行った場合には, 支持基底面 を両下腿から両膝関節部に移し, 膝関節をより屈曲さ せることで下腿による重みを提供し, 強い前方への崩 れを抑えるために大腿二頭筋の膝関節における強い求 心性活動が要求されることが考えられ，このことが今 回の膝立ち位での動作時の大腿二頭筋の筋活動増加に つながったものと思われる。

また，立位・膝立ち位両肢位での前方リーチ動作(2) では, 骨盤の引けを抑えた動作を行ったため, 大殿筋・ 大腿二頭筋供に股関節部において求心性活動が起こつ たものと考えられる。通常求心性活動に比べ, 遠心性 活動では筋出力が増大寸ると考えられているが 9), 遠 心性収縮では運動単位の参加がされずらいことも知ら れている。今回の実験では大殿筋でのみ各動作間での 比較で立位リーチと立位リーチ(2)間において有意差が 認められており, 筋出力の増大が起こったものと考え られる。これは通常のリーチ動作では大殿筋の遠心性 の活動を十分に促すだけの負荷がかかっていなかった ものが，骨盤の引けを抑えさせたことにより，股関節 伸展での重心の前方変位に対する姿勢保持のための負 荷量が増大し，これが大殿筋の強い収縮を促したもの と考えられる。また, 大腿二頭筋は今回の 4 つの動作の 中で膝立ちリーチ(2)にて最も全体における筋活動の割 合が大きい結果となった。山下やBasmajianらは，二関 節筇は隣接する関節に対して共同的に働く際には, 負 荷量の増加に伴い筋放電量の増加が認められるが, 共同 作用と拮抗作用を同時に果たす際には, 負荷量の増加に 伴い筋放電量が増加しない場合があるとしている 10-12)。 膝立ち位リーチ(2)では大腿二頭筋は股関節・膝関節両 部において求心性活動が起こったものと考えられ，こ のことも1つの要因になったと考えられる。

通常, 今回行った前方リーチ動作は, バランス機能の 評価・治療といったイメージが強いと思われる。しか し, そのバランスを保持するためには当然筋活動が必要 となり, その際どのような筋活動が起こっているのかを
把握し評価する必要がある。今回の実験から, 立位での リーチに比べ膝立ち位でのリーチにて大腿二頭筋の全 体における筋活動の割合の増加が, また立位リーチ(2)に て大殿筋の筋活動の割合の増加が考えられ, 動作を行う 肢位や動作方法により筇活動に変化が表れることが明 らかとなった。また, 今回被験筋とした, 4つの筋は様々 な疾患において立ち上がりや歩行といった動作時に, 筋 活動の低下や健常人とは異なる筋活動の延長が起こる 13,14) といった報告がなされており，これらが動作阻害の 要因となっていると考えられる。このことから,これら の肢位や動作方法を組み合わせることにより, 今回測定 した筋に問題を抱える患者のより特定した筋肉の評価, 治療につながるのではないかと考えている。

\section{引用文献}

1) 盛 允彦, 久保山晃成, 山口祐子・他 : 膝立ち位と立位の筋 活動における比較. 理学療法学, 2004, 31: 365.

2) 鏑木 誠, 新地友和, 梅木千恵子・他 : 静的な立位と膝立ち 位の姿勢制御の比較一無拘束型加速度計測法による検討一. 理学療法学, 2001, 28: 157.

3) 前田里美, 早川由佳里, 佐藤桂子・他 : 膝立ち位における側 方重心移動動作の運動学的分析. 理学療法の歩み, 2003, 14: 45-50.

4) 木下一雄, 中村香織, 中村高良・他 : 膝立ち位における筋活 動に関する基礎的研究. 総合リ八, 2006, 34(9): 894-896.

5) Duncan PW, Weiner DK, Chandler J, et al.: Functional reach: A new clinical measure of balance. J Georontol Med Sci, 1992, 45(6): 192-197.

6) Duncan PW, Studenski S, Chandler J, et al.: Functional reach: Predictive validity in a sample of elderly male veterans. J Georontol Med Sci, 1992, 47(3): 93-98.

7) Carr JH, Shepherd RB (著), 潮見泰藏, 斎藤昭彦（訳）: 脳卒 中の運動療法. 医学書院, 東京, 2004, pp46-47.

8) 岡田修一: 加齢と平衡反応一外乱刺激に対する高齢者の立位 姿勢応答一. 理学療, 1996, 13(3): 183-188.

9) 奈良 勲, 岡西哲也 (監修) : 筋力 第1版. 医歯薬出版, 東 京, 2004, p123.

10) 山下謙智: EMGのBiomechanicsへの応用一二関節筋の放電パ ターン その特異性一. J J SPORTS SCI, 1983, 2(9): 717-727.

11）山下謙智: ヒトの随意運動にみられる筋活動電位抑制現象に 関する研究 第II報一二関節同時運動時, 二関節筋に現れる 抑制現象について一. 関西医大誌, 1982, 34: 427-452.

12) Basmajian JV: Muscle Alive. Muscle Interactions. Baltimore. Williams and Wilkins, Baltimore, 1985, pp223-245.

13) 袴田さち子, 石井慎一郎, 佐藤美和子 - 他: 大殿筋収縮不全 が仙腸関節の不安定性に及ぼす影響. 理学療法学, 1998, 25: 554.

14) 山本留七, 岡西哲夫, 系永明美 - 他: 片麻痺歩行における健 側の代償性一第2報 大殿筋の態度について一. 臨床理学療 法, 1982, 9(3): 121-122. 